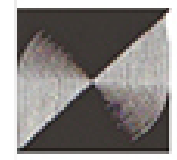

\section{Assicuttusa, \\ Sociedady Desarsollo}

Agricultura, Sociedad y Desarrollo

ISSN: $1870-5472$

asyd@colpos.mx

Colegio de Postgraduados

México

Flores-Cruz, Luis A.; García-Salazar, José A.; Mora-Flores, José S.; Pérez-Soto, Francisco PRODUCCIÓN DE MAÍZ (Zea mays L.) EN EL ESTADO DE PUEBLA: UN ENFOQUE DE EQUILIBRIO ESPACIAL PARA IDENTIFICAR LAS ZONAS PRODUCTORAS MÁS COMPETITIVAS

Agricultura, Sociedad y Desarrollo, vol. 11, núm. 2, abril-junio, 2014, pp. 223-239

Colegio de Postgraduados

Texcoco, Estado de México, México

Disponible en: http://www.redalyc.org/articulo.oa?id=360533099006

Cómo citar el artículo

- Número completo

- Más información del artículo

Página de la revista en redalyc.org

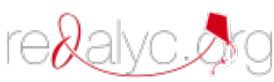

Sistema de Información Científica

Red de Revistas Científicas de América Latina, el Caribe, España y Portugal Proyecto académico sin fines de lucro, desarrollado bajo la iniciativa de acceso abierto 


\title{
PRODUCCIÓN DE MAÍZ (Zea mays L.) EN EL ESTADO DE PUEBLA: UN ENFOQUE DE EQUILIBRIO ESPACIAL PARA IDENTIFICAR LAS ZONAS PRODUCTORAS MÁS COMPETITIVAS
}

\author{
MAIZE PRODUCTION (Zea mays L.) IN THE STATE OF PUEBLA: USING SPATIAL \\ EQUILIBRIUM APPROACH TO IDENTIFY THE MOST COMPETITIVE PRODUCING ZONES
}

\author{
Luis A. Flores-Cruz ${ }^{1}$, José A. García-Salazar*1, José S. Mora-Flores ${ }^{1}$, Francisco Pérez-Soto² \\ Economía. Campus Montecillo. Colegio de Postgraduados. 56230. Km.36.5. Carretera \\ México-Texcoco, Edo. de México (jsalazar@colpos.mx). ${ }^{2}$ DICEA. Universidad Autónoma \\ Chapingo. 56230. Km 38.5 Carretera México-Texcoco, Edo. de México.
}

\begin{abstract}
RESUMEN
La focalización de recursos por parte del Gobierno para apoyar la producción de maíz en aquellas zonas con alto potencial productivo requiere la identificación de las zonas más competitivas. Para determinar las zonas productoras de maíz (Zea Mays $\mathrm{L}_{\text {.) }}$ más competitivas en el estado de Puebla se formuló y se obtuvo la solución de un modelo de equilibrio espacial e inter-temporal que considera la demanda, la oferta, la distribución de la producción e importaciones, y el abasto del consumo en cada zona consumidora. El modelo usó datos del periodo 2008 - 2010 y se obtuvieron cuatro soluciones que corresponden al año base y a reducciones graduales en la disponibilidad de maíz para consumo proveniente de una disminución en las importaciones estatales. Los resultados indican que ante una disminución de importaciones estatales en $\mathbf{2 5} \%$, la producción de maíz de Cholula y Tecamachalco aumentaría en 56 y 34 mil ton, respectivamente, definiendo a estas regiones como las más competitivas. En general, las zonas productoras más competitivas son aquellas que registran los mayores rendimientos y están ubicadas más cerca de los centros de consumo. Con base en los resultados se recomienda que el Gobierno apoye la producción de maíz en el estado, específicamente en las zonas más competitivas.
\end{abstract}

Palabras clave: consumo, importación, oferta, programación lineal.

\section{INTRODUCCIÓN}

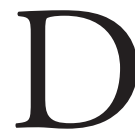
esde el punto de vista alimentario, económico y social, el maíz es el cultivo más importante de México. En el año promedio 2008 - 2010, el consumo nacional aparente fue de

* Autor responsable * Author for correspondence.

Recibido: enero, 2013. Aprobado: mayo, 2014.

Publicado como ARTíCULO en ASyD 11: 223-239. 2014.

\section{Abstract}

Focalization of resources by the government to support maize production in the zones with high productive potential requires identifying the most competitive zones. In order to determine the most competitive maize (Zea mays L.) producing zones in the state of Puebla, a solution for a spatial and inter-temporal equilibrium model was obtained that takes into account the demand, the offer, the distribution of production and imports, and the supply for consumption in each consumer zone. The model used data from the 20082010 period and four solutions were obtained corresponding to the base year and to gradual reductions in maize availability for consumption, as a result of the decrease in state imports. Results indicate that faced with a reduction of state imports of $25 \%$, maize production in Cholula and Tecamachalco would increase in $\mathbf{5 6}$ and 34 thousand tons, respectively, defining these regions as the most competitive. In general, the most competitive production zones are those that show the highest yields and are located closer to the consumption centers. Based on the results, it is recommended that the government support maize production in the state, particularly in the most competitive zones.

Key words: consumption, imports, offer, linear programming.

\section{INTRODUCTION}

$\mathrm{F}$ rom a dietary, economic and social perspective, maize is the most important crop in México. During the average year 2008-2010, the apparent national consumption was 30.81 million tons, of which 21.03 were of white maize, with this being the most important market; 9.78 million tons were of yellow maize (García and Ramírez, 2012). Although production has increased in $50 \%$ since 
30.81 millones de ton, de las cuales 21.03 fueron de maíz blanco, siendo este mercado el más importante; 9.78 millones de ton fueron de maíz amarillo (García y Ramírez, 2012). A pesar de que la producción ha aumentado en $50 \%$ desde 1994, año de inicio del Tratado de Libre Comercio de América del Norte (TLCAN), dicha producción promedió 22.7 millones de ton cada año en el período 2006-2010. La dependencia por importaciones se ubicó en $34 \%$ en 2006-2008 (Turrent et al., 2012).

En Puebla, en el año promedio 2008/2010 se consumieron 1.74 millones de ton de maíz; de estas, 1.24 millones fueron maíz blanco y 0.49 millones maíz amarillo (García y Ramírez, 2012). Puebla se ubica entre los ocho principales estados productores de maíz, aportando una oferta de 1.08 millones de ton, lo que representa $4.6 \%$ de la producción anual nacional (SIAP-SAGARPA, 2012a). Datos del INEGI (2007) indican que en el estado, de un total de 994 mil ha dedicadas a la agricultura, 60.1\% se siembran con maíz y $91.3 \%$ de tal superficie se cultivó bajo condiciones de temporal. Pese a la alta producción del estado, las estimaciones sobre el consumo estatal aparente indican que existe un fuerte déficit del producto; en el año promedio 2008/2010 fue de 395 mil ton de maíz blanco y de 497 mil ton de maíz amarillo (García y Ramírez, 2012).

Desde el pasado se han dado varios intentos por reducir el déficit estatal de maíz. Uno de los programas más importantes, que sentó las bases para nuevas estrategias y programas dirigidos a la autosuficiencia alimentaria, fue el Plan Puebla. El programa empezó a operar en 1967 y oficialmente dejó de funcionar en 2002. En dicho programa se usó un modelo participativo para capacitar extensionistas y proporcionar servicios (tecnología, crédito y seguro agrícola) que contribuyeron a duplicar el rendimiento del maíz de 43300 pequeńos productores de temporal, al pasar en promedio de 1300 a $3100 \mathrm{~kg}$ por ha entre 1967 y 2000. También el ingreso familiar se incrementó en $24 \%$. En su momento, el programa fue considerado como modelo para México y otros países (Felstehausen y Díaz, 1985). Durante el tiempo que se mantuvo en operación, el plan no solo experimentó grandes logros en el aspecto técnico productivo sino que su funcionamiento generó el establecimiento de otros programas técnicos, de organización de productores y acumulación de conocimiento para instituir programas de enseñanza y capacitación (Sánchez et
1994, year when the North American Free Trade Agreement (NAFTA) began, for the 2006-2010 period the production was 22.7 million tons each year in average. The dependency on imports was $34 \%$ in 2006-2008 (Turrent et al., 2012).

In Puebla, during the average year 2008-2010, 1.74 million tons of maize were consumed; of these, 1.24 million were white maize and 0.49 million yellow maize (García and Ramírez, 2012). Puebla is located among the eight principal maize producing states, contributing an offer of 1.08 million tons, which represents $4.6 \%$ of the national annual production (SIAP-SAGARPA, 2012a). Data from INEGI (2007) indicate that in the state, of a total of 994 thousand ha devoted to agriculture, $60.1 \%$ are sown with maize and $91.3 \%$ of the surface was cultivated under rainfed conditions. In spite of the high production of the state, estimations about the apparent state consumption indicate that there is a strong deficit in the product; in the average year 2008-2010, it was 395 thousand tons of white maize and 497 thousand tons of yellow maize (García and Ramírez, 2012).

In the past there have been several attempts to reduce the state maize deficit. One of the most important programs, which established the bases for new strategies and programs directed at food autosufficiency, was Plan Puebla. The program began to operate in 1967 and it officially ceased to function in 2002. In this program, a participative model was used to train extension workers and to provide services (technology, credit and agricultural insurance) that contributed to double the maize yield of 43 300 small-scale producers with rainfed conditions, when the average went from 1300 to $3100 \mathrm{~kg}$ per ha between 1967 and 2000. The family income also increased in $24 \%$. In its moment, the program was considered a model for México and other countries (Felstehausen and Díaz, 1985). During the time that it was in operation, the plan not only experienced great achievements in the technical productive aspect, but its functioning also generated the establishment of other technical programs, of producers' organization, and of knowledge accumulation to implement teaching and training programs (Sánchez et al., 2011).

In order to reduce the dependency on maize, the Mexican government recently announced an investment of 138 million dollars for a 10-year 
al., 2011).

Para reducir la dependencia en maíz, el Gobierno Mexicano anunció recientemente una inversión de 138 millones de dólares en un programa de 10 años para incrementar la producción nacional de maíz. El programa es conocido como Modernización Sustentable de la Agricultura Tradicional (MasAgro). La estrategia es impulsar el uso de variedades mejoradas, así como mejorar el servicio de extensión agrícola para un manejo conservacionista de los recursos agrícolas de los pequeños y medianos productores de maíz (SAGARPA-CIMMYT, 2011). El Gobierno también ha apoyado la adopción de híbridos de maíz genéticamente modificados, habiendo autorizado su siembra a las escalas experimental y piloto en el ańo 2011, motivo de gran controversia en la parte norte del país (Turrent et al., 2012).

Los déficits de rendimiento son mayores entre los pequeños y medianos productores de maíz de temporal. Esta observación es consistente con evaluaciones internacionales (FAO, 2011 y 2012). Como este sector de productores tiene acceso limitado al crédito formal, al riego, y ha sido desatendido por los servicios de extensión en las últimas dos décadas, los productores producen por debajo de su potencial. El sector también sufre de organización inoperante que limita cualquier incremento en la productividad (Turrent et al., 2012). Se estima que los productores de temporal de maíz operan al $57 \%$ de su potencial productivo, dejando un déficit de rendimiento de $43 \%$ (FAO, 2011 y 2012). La mayor parte de las regiones operaban a menos de $50 \%$ de su potencial. Eliminar este déficit de rendimiento añadiría más de nueve millones de ton a la producción nacional (Turrent, 2009; Turrent et al., 2012). Estimaciones indican que para el estado de Puebla se tiene un potencial de producción de maíz de 1.245 millones de ton, de las cuales $99 \%$ corresponde a maíz blanco (García y Ramírez, 2012). El potencial productivo es diferente en cada región; de igual manera, el nivel de competitividad también es diferente en cada Distrito de Desarrollo Rural (DDR) de la entidad.

El potencial con el que cuenta el estado de Puebla para elevar la producción de maíz en la entidad (García y Ramírez, 2012), la existencia de MasAgro y el fuerte déficit comercial en la entidad indican que el Gobierno debería focalizar recursos que permitan incrementar la oferta del cereal. El aumento de la producción reduciría la dependencia alimentaria program to increase the national production of maize. The program is known as Sustainable Modernization of Traditional Agriculture (Modernización Sustentable de la Agricultura Tradicional, MasAgro). The strategy is to foster the use of improved varieties, as well as to improve the agricultural extension service for a conservationist management of agricultural resources of the small and medium-scale maize producers (SAGARPA-CIMMYT, 2011). The government has also supported the adoption of genetically modified maize hybrids, having authorized their planting at the experimental and pilot scales in 2011, cause for great controversy in the northern part of the country (Turrent et al., 2012).

The yield deficits are greater between small and medium-scale maize producers under rainfed conditions. This observation is consistent with international evaluations (FAO, 2011 and 2012). Since this sector of producers has limited access to formal credit and to irrigation, and they have been neglected by the extension services during the past two decades, the producers produce below their potential. The sector also suffers from ineffective organization that limits any increase in productivity (Turrent $e t$ al., 2012). It is estimated that rainfed maize producers operate at $57 \%$ of their productive potential, leaving a deficit in yield of $43 \%$ (FAO, 2011 and 2012). Most of the regions operated at less than $50 \%$ of their potential. Eliminating this deficit in yield would add more than nine million tons to the national production (Turrent, 2009; Turrent et al., 2012). Estimations indicate that for the state of Puebla there is a potential for maize production of 1.245 million tons, of which $99 \%$ correspond to white maize (García and Ramírez, 2012). The productive potential is different in each region; likewise, the level of competition is also different in each Rural Development District (Distrito de Desarrollo Rural, DDR) in the state.

The potential that the state of Puebla has to increase maize production in the entity (García and Ramírez, 2012), the existence of MasAgro, and the strong commercial deficit in the state, indicate that the government should assign resources to allow for an increase in the cereal's offer. The increase in production would reduce food dependency and imports. If a fast response is required, these resources should be concentrated in those regions where production could be increased in a shorter time; obviously these regions are the most competitive. 
y las importaciones. Si se quiere una respuesta rápida, dichos recursos deberán focalizarse hacia aquellas regiones en las cuales se pueda incrementar la producción en un tiempo más corto; obviamente estas regiones serán las más competitivas.

Se puede decir que una zona productora de maíz es competitiva si las ganancias obtenidas por la venta del producto son positivas (es decir, los ingresos son mayores a los costos de producción) y se tiene cierta participación en el mercado. Dicha región aumentará su competitividad si incrementa su participación en el mercado, obteniendo ganancias (García et al., 2006).

La competitividad en el sector agrícola ha sido estudiada por diversos autores. Con la finalidad de dar elementos para definir la política de transición de una economía cerrada a una economía abierta, dos años antes de la entrada en vigor del TLCAN, Salcedo et al. (1993) realizaron un estudio que cubrió 24 estados de México, con diferentes niveles de rendimientos, costos de producción, subsidios, grados de competitividad y eficiencia en la producción de maíz. Con el objetivo de sentar las bases para la reconversión de la agricultura y analizar los posibles efectos del Tratado de Libre Comercio de América del Norte sobre los mercados agrícolas,. Matus y Puente (1992) realizaron un estudio sobre la competitividad y las ventajas comparativas no solo de la producción de maíz en México, sino de los cultivos más importantes en la estructura productiva del sector agrícola de cada estado. Los resultados de ambos estudios indican que la competitividad y las ventajas comparativas de maíz son distintas para cada sistema de producción y que, por lo tanto, los efectos de la liberación comercial serían distintos para cada sistema.

González y Alferes (2010) concluyen que $85 \%$ del volumen de maíz obtenido en México es producido en condiciones de competitividad privada y $73.5 \%$ de la superficie nacional es cultivada con esa gramínea. La competitividad y las ventajas comparativas para producir maíz en México han crecido.

Los estudios anteriores cuentan con una impecable lógica y desagregan de manera muy detallada la estructura de costos, pero no consideran la magnitud del consumo y el complejo proceso de distribución del producto desde la zona productora hasta la zona consumidora. Entre los factores que afectan la competitividad de un producto se puede mencionar el nivel de rendimiento, el precio de venta, los costos
It could be said that a maize producing zone is competitive if the earnings obtained from the sale of the product are positive (that is, the income is higher than the production costs), and if there is a certain participation in the market. Such a region would increase its competitiveness if it increases its participation in the market, obtaining profits (García et al., 2006).

Competitiveness in the agricultural sector has been studied by various authors. With the aim of giving elements to define the transition policy from a closed economy to an open economy, two years prior to the enforcement of NAFTA, Salcedo et al. (1993) performed a study that covered 24 states in México, with different levels of yields, production costs, subsidies, degrees of competitiveness and efficiency in maize production. With the goal of setting the bases for reconversion of agriculture and analyzing the possible effects of NAFTA on agricultural markets, Matus and Puente (1992) carried out a study about competitiveness and the comparative advantages not only of maize production in México, but also of the most important crops in the productive structure of the agricultural sector in each state. The results from both studies indicate that competitiveness and comparative advantages for maize are different in each production system and that, therefore, the effects of trade liberalization would be different for each system.

González and Alferes (2010) concluded that $85 \%$ of the maize obtained in México is produced under conditions of private competitiveness and $73.5 \%$ of the national surface is cultivated with this pulse. The competitiveness and comparative advantages for maize production in México have increased.

The previous studies have an impeccable logic and disaggregate in a very detailed manner the structure of costs, but they do not consider the magnitude of consumption and the complex process of distribution of the product from the producing zone to the consuming zone. Among the factors that affect the competitiveness of a product, the following can be mentioned: level of yield, price of sale, costs of production and relative location of producing zones with regard to centers of consumption, which determines the costs of transport, the location of points of entry for imports, and the costs of storage (García, et al., 2006; SAGARPA, 2003). An increase in the yield of a maize producing region would 
de producción y la ubicación relativa de las zonas productoras respecto a los centros de consumo, lo cual determina los costos de transporte, la ubicación de los puntos de internación de las importaciones y los costos de almacenamiento (García, et al., 2006; SAGARPA, 2003). Un aumento en el rendimiento en una región productora de maíz mejoraría la competitividad de esta región por las siguientes razones: a) el mayor ingreso por hectárea aumentaría la ganancia del productor; $y$ b) la mayor oferta disponible permitiría ampliar la participación de la región en el mercado.

Determinar el nivel de competitividad considerando la oferta, la demanda y el proceso de distribución de maíz en cada distrito de desarrollo es importante por las siguientes razones: a) fortalece la producción de maíz para incorporarse a las cadenas de valor regionales; b) permite conocer la forma en cómo se abastece el consumo en cada mercado; c) se identifica cómo se distribuye la producción de las zonas productoras y la producción máxima posible a alcanzar; y d) muestra hasta qué punto es posible aumentar la producción con una reducción de importaciones.

Considerando la importancia del maíz para el estado de Puebla, la presente investigación tuvo como objetivo determinar las áreas de producción más competitivas y con mayor potencial de crecimiento desde el punto de vista logístico, costos y ubicación de las zonas productoras y consumidoras. Como hipótesis se planteó que las zonas con mayor rendimiento y más cercanas a las zonas de consumo tienen mayor potencial de crecimiento $y$, por consiguiente, son las más competitivas en el estado.

\section{Materiales y Métodos}

\section{Modelo}

Para alcanzar los objetivos y probar la hipótesis planteada se usó un modelo de equilibrio espacial e inter-temporal. La formulación del modelo se basó en Takayama y Judge (1971) y la función objetivo del modelo maximiza la ganancia neta, el indicador para medir la competitividad. La estructura económica del modelo, basado en la teoría microeconómi$\mathrm{ca}$, supone que existen varias regiones que producen y consumen maíz. Las regiones consumidoras están conectadas a las que son productoras en el estado y improve the competitiveness of this region because of the following reasons: a) the higher income per hectare would increase the producer's earnings; and b) the greater available offer would allow broadening the region's participation in the market.

Determining the level of competitiveness by taking into account the offer, the demand and the maize distribution process in each development district is important for the following reasons: a) it strengthens maize production to be incorporated into the regional value chains; b) it allows understanding the way consumption is supplied in each market; c) it identifies how the product is distributed in producing zones, and the maximum possible production to be attained; and d) it shows how much it is possible to increase the production with a reduction in imports.

Taking into account the importance of maize for the state of Puebla, this study had the objective of determining the most competitive production areas and with greatest potential for growth from the point of view of logistics, costs and location of producing and consuming zones. As hypothesis, it was suggested that the zones with higher yields and closer to the consumption zones have a better potential for growth and, consequently, are the most competitive in the state.

\section{Materials ANd Methods}

\section{Model}

To reach the objectives and test the hypothesis set out, a spatial and inter-temporal equilibrium model was used. The formulation of this model was based on Takayama and Judge (1971), and the objective function of the model maximizes the net profit, indicator used to measure competitiveness. The economic structure of the model, based on microeconomic theory, assumes that there are several regions that produce and consume maize. The consuming regions are connected to the producing regions in the state, and to import limits through transportation costs. When the volume of maize transported is higher, a decrease in the unitary cost of transport is achieved; however, because of the complexity and numerous routes considered in the study, it is assumed that transport costs are independent from volume, which implies the inexistence of economies of scale (Maddala and 
a fronteras de importación a través de los costos de transporte. Cuando el volumen de maíz que se transporta es mayor se logra una disminución en el costo unitario de transporte; sin embargo, por la complejidad y gran cantidad de rutas que se consideran en el trabajo se supone que los costos de transporte son independientes del volumen, lo cual implica la inexistencia de economías de escala (Maddala y Miller, 1991). El análisis inter-temporal considera dos periodos (ciclos de producción) y permite que los excesos de producción que ocurran en uno de éstos se puedan almacenar.

Considerando $t(t=1,2 \ldots T=12)$ periodos de tiempo, $j(j=1,2 \ldots J=8)$ regiones consumidoras de

$$
\begin{aligned}
& \max Z=\sum_{t=1}^{T} \sum_{j=1}^{J}\left[p_{i t} y_{j t}\right]+\sum_{t=1}^{T} \sum_{d=1}^{D}\left[p_{d t} y_{d t}\right] \\
& -\sum_{t=1}^{T} \sum_{i=1}^{I}\left[c p_{h t} x_{h t}\right]-\sum_{t=1}^{T} \sum_{i=1}^{I}\left[c p_{i t} x_{i t}\right] \\
& -\sum_{t=1}^{T} \sum_{r=1}^{R}\left[c p_{r t} x_{r t}\right]-\sum_{t=1}^{T} \sum_{s=1}^{S}\left[c p_{s t} x_{s t}\right] \\
& -\sum_{t=1}^{T} \sum_{n=1}^{N}\left[p_{n t} x_{n t}\right]-\sum_{t=1}^{T} \sum_{m=1}^{M}\left[p_{m t} x_{m t}\right] \\
& -\sum_{t}^{T} \sum_{h=1}^{H} \sum_{j=1}^{J}\left[c t_{h j t} x_{h j t}\right]-\sum_{t}^{T} \sum_{i=1}^{I} \sum_{j=1}^{J}\left[c t_{i j t} x_{i j t}\right] \\
& -\sum_{t}^{T} \sum_{r=1}^{R} \sum_{d=1}^{D}\left[c t_{r d t} x_{r d t}\right]-\sum_{t}^{T} \sum_{s=1}^{S} \sum_{d=1}^{D}\left[c t_{s d t} x_{s d t}\right] \\
& \max Z=\sum_{t=1}^{T} \sum_{j=1}^{J}\left[p_{i t} y_{j t}\right]+\sum_{t=1}^{T} \sum_{d=1}^{D}\left[p_{d t} y_{d t}\right] \\
& -\sum_{t=1}^{T} \sum_{i=1}^{I}\left[c p_{h t} x_{h t}\right]-\sum_{t=1}^{T} \sum_{i=1}^{I}\left[c p_{i t} x_{i t}\right] \\
& -\sum_{t=1}^{T} \sum_{r=1}^{R}\left[c p_{r t} x_{r t}\right]-\sum_{t=1}^{T} \sum_{s=1}^{S}\left[c p_{s t} x_{s t}\right] \\
& -\sum_{t=1}^{T} \sum_{n=1}^{N}\left[p_{n t} x_{n t}\right]-\sum_{t=1}^{T} \sum_{m=1}^{M}\left[p_{m t} x_{m t}\right] \\
& -\sum_{t}^{T} \sum_{h=1}^{H} \sum_{j=1}^{J}\left[c t_{h j t} x_{h j t}\right]-\sum_{t}^{T} \sum_{i=1}^{I} \sum_{j=1}^{J}\left[c t_{i j t} x_{i j t}\right] \\
& -\sum_{t}^{T} \sum_{r=1}^{R} \sum_{d=1}^{D}\left[c t_{r d t} x_{r d t}\right]-\sum_{t}^{T} \sum_{s=1}^{S} \sum_{d=1}^{D}\left[c t_{s d t} x_{s d t}\right] \\
& -\sum_{t}^{T} \sum_{n=1}^{N} \sum_{j=1}^{J}\left[c t_{n j t} x_{n j t}\right]-\sum_{t}^{T} \sum_{m=1}^{M} \sum_{j=1}^{j}\left[c t_{m j t} x_{m j t}\right] \\
& -\sum_{t}^{T} \sum_{h=1}^{H}\left[c a_{h t, t+1} x_{h t, t+1}\right]-\sum_{t}^{T} \sum_{i=1}^{I}\left[c a_{i t, t+1} x_{i t, t+1}\right] \\
& -\sum_{t}^{T} \sum_{r=1}^{R}\left[c a_{r t, t+1} x_{r t, t+1}\right]-\sum_{t}^{T} \sum_{s=1}^{S}\left[c a_{s t, t+1} x_{s t, t+1}\right]
\end{aligned}
$$$$
-\sum_{t}^{T} \sum_{n=1}^{N} \sum_{j=1}^{J}\left[c t_{n j t} x_{n j t}\right]-\sum_{t}^{T} \sum_{m=1}^{M} \sum_{j=1}^{j}\left[c t_{m j t} x_{m j t}\right]
$$$$
-\sum_{t}^{T} \sum_{h=1}^{H}\left[c a_{h t, t+1} x_{h t, t+1}\right]-\sum_{t}^{T} \sum_{i=1}^{I}\left[c a_{i t, t+1} x_{i t, t+1}\right]
$$$$
-\sum_{t}^{T} \sum_{r=1}^{R}\left[c a_{r t, t+1} x_{r t, t+1}\right]-\sum_{t}^{T} \sum_{s=1}^{S}\left[c a_{s t, t+1} x_{s t, t+1}\right]
$$

Miller, 1991). The inter-temporal analysis considers two periods (production cycles) and allows for production excesses that happen in one of these to be stored.

Considering $t(t=1,2 \ldots T=12)$ periods of time, $j(j=1,2 \ldots J=8)$ consuming regions of white maize, $d(d=1,2 \ldots D=7)$ and of yellow maize, $h(h=1,2 \ldots H=7)$; white maize producing regions with irrigation, $i(i=1,2 \ldots$ $I=8)$ white maize under rainfed conditions, $r(r=1=R=1)$ yellow maize with irrigation, $s(s=1,2, \mathrm{~S}=3)$ and yellow maize under rainfed conditions; $n(n=1=\mathrm{N}=1)$ origins of white maize imports received by Puebla, and $m(m=1=M=1)$ of yellow maize received by Puebla, the mathematical representation of the model is:

Subject to:

$$
\begin{aligned}
& \sum_{h=1}^{H}\left[x_{h j t}\right]+\sum_{i=1}^{I}\left[x_{i j t}\right]+\sum_{n=1}^{N}\left[x_{n j t}\right] \geq y_{j t} \\
& \sum_{r=1}^{R}\left[x_{r d t}\right]+\sum_{s=1}^{S}\left[x_{s d t}\right]+\sum_{m=1}^{M}\left[x_{m d t}\right] \geq y_{d t}
\end{aligned}
$$


sujeto a:

$$
\begin{aligned}
& \sum_{h=1}^{H}\left[x_{h j t}\right]+\sum_{i=1}^{I}\left[x_{i j t}\right]+\sum_{n=1}^{N}\left[x_{n j t}\right] \geq y_{j t} \\
& \sum_{r=1}^{R}\left[x_{r d t}\right]+\sum_{s=1}^{S}\left[x_{s d t}\right]+\sum_{m=1}^{M}\left[x_{m d t}\right] \geq y_{d t} \\
& \sum_{j=1}^{J}\left[x_{i j t}\right] \leq x_{i t}+x_{i t-1, t}-x_{i t, t+1} \\
& \sum_{j=1}^{J}\left[x_{h j t}\right] \leq x_{h t}+x_{h t-1, t}-x_{h t, t+1} \\
& \sum_{d=1}^{D}\left[x_{r d t}\right] \leq x_{r d t}+x_{r t-1, t}-x_{r t, t+1} \\
& \sum_{d=1}^{D}\left[x_{s d t}\right] \leq x_{s t}+x_{s t-1, t}-x_{s t, t+1} \\
& \sum_{j=1}^{J}\left[x_{n j t}\right] \leq x_{n t} \\
& \sum_{d=1}^{D}\left[x_{m d t}\right] \leq x_{m d t} \\
& y_{j 2} y_{t d} x_{h t}, x_{i p} \ldots, x_{s t, t+1}
\end{aligned}
$$

Donde para el periodo t: $p_{i t}$ es el precio al consumidor de maíz en la región $j ; y_{i t}$ es la cantidad consumida de maíz blanco en $j ; p_{d t}$ es el precio al consumidor de maíz en la región $d ; y_{d t}$ es la cantidad consumida de maíz amarillo en $d ; c p_{h t}$ es el costo de producción del maíz blanco en riego en la región $h ; x_{b t}$ es la cantidad producida de maíz blanco en riego en la región $h ; c p_{i t}$ es el costo de producción del maíz blanco en temporal en $i ; x_{i t}$ es la cantidad producida de maíz blanco en temporal en la región $i ; p_{r t}$ es el costo de producción de maíz amarillo en riego en $r ; x_{r t}$ es la cantidad producida de maíz amarillo en riego en la región $r ; c p_{s t}$ es el costo de producción de maíz amarillo en temporal en $s ; x_{s t}$ es la cantidad producida de maíz amarillo temporal en $s ; p_{n t}$ es el precio de importación de maíz blanco; $x_{n t}$ es la cantidad importada de maíz blanco; $p_{m t}$ es el precio de importación de maíz amarillo; $x_{m t}$ es la cantidad importada de maíz amarillo; $c t_{h j t}$ es el costo de transporte del maíz blanco en riego de $h$ a $j$; $x_{h j t}$ son los envíos de maíz blanco en riego de $h$ a $j$; $c t_{i j t}$ es el costo de transporte del maíz blanco en temporal

$$
\sum_{j=1}^{J}\left[x_{i j t}\right] \leq x_{i t}+x_{i t-1, t}-x_{i t, t+1}
$$$$
\sum_{j=1}^{J}\left[x_{h j t}\right] \leq x_{h t}+x_{h t-1, t}-x_{h t, t+1}
$$

$$
y_{j t}, y_{t d}, x_{b t}, x_{i t}, \ldots, x_{s t, t+1}
$$

Where for the period $t: p_{i t}$ is the maize price for the consumer in region $j ; y_{i t}$ is the amount consumed of white maize in $j ; p_{d t}$ is the maize price for the consumer in region $d ; y_{d t}$ is the amount consumed of yellow maize in $d ; c p_{h t}$ is the production cost of white maize under irrigation in region $h ; x_{h t}$ is the amount produced of white maize under irrigation in region $h ; c p_{i t}$ is the production cost of white maize under rainfed conditions in $i ; x_{i t}$ is the amount produced of white maize under rainfed conditions in region $i ; p_{r t}$ is the production cost of yellow maize under irrigation in $r ; x_{r t}$ is the amount produced of yellow maize under irrigation in region $r ; c p_{s t}$ is the production cost of yellow maize under rainfed conditions in $s ; x_{s t}$ is the amount produced of yellow maize under rainfed conditions in $s ; p_{n t}$ is the import price for white maize; $x_{n t}$ is the amount imported of white maize; $p_{m t}$ is the import price for yellow maize; $x_{m t}$ is the amount imported of yellow maize; $c t_{b j t}$ is the transportation cost of white maize under irrigation from $h$ to $j ; x_{h j t}$ are the shipments of white maize under irrigation from $h$ to $j$; $c t_{i j t}$ is the transportation cost of white maize under rainfed conditions from $i$ to $j ; x_{i j t}$ are the shipments of white maize under rainfed conditions from $i$ to $j$; $c t_{r d t}$ is the transportation cost of yellow maize under irrigation from $r$ to $d ; x_{r d t}$ are the shipments of yellow maize under irrigation from $r$ to $d ; c t_{s d t}$ is the transportation cost of yellow maize 
de $i$ a $j ; x_{i j t}$ son los envíos de maíz blanco en temporal de $i$ a $j$; $c_{r d t}$ es el costo de transporte del maíz amarillo en riego de $r$ a $d ; x_{r d t}$ son los envíos de maíz amarillo en riego de $r$ a $d ; c t_{s d t}$ es el costo de transporte del maíz amarillo en temporal de $s$ a $d ; x_{s d t}$ son los envíos de maíz amarillo en temporal de $s$ a $d ; c t_{n j t}$ es el costo de transporte del maíz blanco de $n$ a $j ; x_{n j t}$ son los envíos de maíz blanco de $n$ a $j$; $c t_{m d t}$ es el costo de transporte del maíz amarillo de $\mathrm{m}$ a $d ; x_{m d t}=$ envíos de maíz amarillo de $m$ a $d ; c a_{b t, t t 1}$ es el costo de almacenamiento de maíz blanco riego en $h$ de $t$ a $t+1 ; x_{h t t+1}$ es la cantidad almacenada de maíz blanco en riego en $h$ de $t$ a $t+1 ; c a_{i t, t+1}$ es el costo de almacenamiento de maíz blanco en temporal en $i$ de $t$ a $t+1 ; c a_{i t, t+1}$ es la cantidad almacenada de maíz blanco en temporal en $i$ de $t$ a $t+1 ; c a_{r t, t+1}$ es el costo de almacenamiento de maíz amarillo en riego en $r$ de $t$ y $t+1 ; x_{r t, t+1}$ es la cantidad almacenada de maíz amarillo en riego en $r$ de $t$ y $t+1 ; c a_{s t, t+1}$ es el costo de almacenamiento de maíz amarillo en temporal en $s$ de $t$ y $t+1 ; x_{s t, t+1}$ es la cantidad almacenada de maíz amarillo en temporal en $s$ de $t$ y $t+1$.

La ecuación (1) representa la función objetivo del modelo y maximiza ganancia neta, la cual es igual a los ingresos por la venta del producto, menos los costos de producción, menos de importaciones, menos los costos de transporte y menos los costos de almacenamiento.

La función objetivo está sujeta a nueve restricciones. La restricción (2) indica cómo se abastece el consumo de maíz blanco de las regiones $j$ a través de recepciones de maíz provenientes de las zonas productoras de maíz blanco en riego y temporal $(h$ e $i)$ y de importaciones $(n)$. La restricción (3) indica cómo se abastece el consumo de maíz amarillo de las regiones $d$ a través de recepciones de maíz provenientes de las zonas productoras de maíz amarillo en riego y temporal $(r$ y $s)$ y de importaciones $(m)$.

Las restricciones (4), (5), (6) y (7) indican cómo se distribuye la producción de las zonas productoras ( $h, i, r y s$ ) en las consumidoras ( $j$ y $d$ ), una vez sumada la variación de inventarios (cantidad almacenada de $t-1$ a $t$, menos cantidad almacena de $t$ a $t+1$ ). Las restricciones (8) y (9) indican cómo se distribuyen las importaciones de $n$ y $m$ a las zonas consumidoras $j$ y $d$. Por último, la restricción (10) establece las condiciones de no negatividad.

Se obtuvieron cuatro soluciones del modelo. La primera representa la situación observada en el año under rainfed conditions from $s$ to $d ; x_{s d t}$ are the shipments of yellow maize under rainfed conditions from $s$ to $d ; c t_{n j t}$ is the transportation cost of white maize from $n$ a $j ; x_{n i t}$ is the shipment of white maize from $n$ to $j ; c t_{m d t}$ is the transportation cost of yellow maize from $m$ to $d ; x_{m d t}$ is the shipment of yellow maize from $m$ to $d ; c a_{h b t t 1}$ is the cost of storage of white maize in $h$ from $t$ to $t+1 ; x_{h t, t+1}$ is the amount of white maize under irrigation stored in $h$ from $t$ to $t+1 ; c a_{i t, t+1}$ is the cost of storage of white maize under rainfed conditions in $i$ from $t$ to $t+1 ; c a_{i t t+1}$ is the amount of white maize under rainfed conditions stored in $i$ from $t$ to $t+1 ; c a_{r t t+1}$ is the cost of storage of yellow maize under irrigation in $r$ from $t$ to $t+1$; $x_{r t, t+1}$ is the amount of yellow maize under irrigation stored in $r$ from $t$ to $t+1 ; c a_{s t, t+1}$ is the cost of storage of yellow maize under rainfed conditions in $s$ from $t$ to $t+1 ; x_{s, t+1}$ is the amount of yellow maize under rainfed conditions stored in $s$ from $t$ to $t+1$.

Equation (1) represents the model's objective function and maximizes the net profit, which is equal to the income for the sale of the product minus the production costs, minus imports, minus transportation costs and minus storage costs.

The objective function is subject to nine restrictions. Restriction (2) indicates how the consumption of white maize in regions $j$ is supplied through reception of maize from producing zones of white maize under irrigation and rainfed conditions $(b$ and $i$ ) and from imports $(n)$. Restriction (3) indicates how the consumption of yellow maize in regions $d$ is supplied through the reception of maize from producing zones of yellow maize under irrigation and rainfed conditions ( $r$ and $s$ ) and imports $(m)$.

Restrictions (4), (5), (6) and (7) indicate how the production from producing zones is distributed ( $h, i, r$ and $s$ ) in the consuming zones ( $j$ and $d$ ), once the variation of inventories is added (amount stored from $t-1$ to $t$, minus amount stored from $t$ to $t+1$ ). Restrictions (8) and (9) indicate how the imports from $n$ and $m$ are distributed to consuming zones $j$ and $d$. Lastly, restriction (10) establishes the conditions of non-negativity.

Four solutions to the model were obtained. The first represents the situation observed in the year of analysis 2008/2010. To determine the most competitive producing zones several scenarios were tested, taking into account a situation of maize scarcity achieved through a gradual decrease in 
de análisis 2008/2010. Para determinar las zonas productoras más competitivas se realizaron varios escenarios, considerando una situación de escasez de maíz lograda a través de una disminución gradual en las importaciones. En los tres escenarios la oferta regional puede aumentar de la situación observada a la potencial para desplazar a las importaciones. El Escenario 1 consideró una reducción de $25 \%$ en las importaciones estatales, y los Escenarios 2 y 3 una reducción de 50 y $75 \%$, respectivamente. Los tres escenarios tomaron en cuenta la producción potencial como límite máximo. Las regiones más competitivas serán aquellas donde aumenta la producción cuando las importaciones se reducen en un menor porcentaje. Debido a que el aumento en la producción no alcanza a cubrir el déficit de maíz amarillo del estado, en los escenarios sólo se reduce la compra de maíz blanco. Suponiendo la inexistencia de superficie siniestrada se obtuvo una nueva producción potencial, usando el rendimiento potencial y la superficie sembrada y se realizaron tres nuevos escenarios con reducción en las importaciones estatales de maíz amarillo en $15 \%$ (Escenario 1), $30 \%$ (Escenario 2) y $50 \%$ (Escenario 3).

En los tres escenarios la producción de maíz en las zonas de riego y temporal se considera como variable endógena. Al disminuir las importaciones, la oferta de maíz aumenta en un rango que va de la producción actual a potencial.

El modelo consideró dos variedades de maíz: blanco y amarillo. La dimensión espacial se incorporó al modelo, dividiendo el estado en ocho regiones productoras y consumidoras. La definición de regiones se realizó considerando la clasificación de los Distritos de Riego reportados por la Secretaría de Agricultura, Ganadería, Desarrollo Rural, Pesca y Alimentación (SIAP-SAGARPA, 2012a). Las regiones consideradas son: Cholula (integrada por 34 municipios), Huauchinango (20 municipios), Izúcar de Matamoros (45 municipios), Libres (24 municipios), Tecamachalco (32 municipios), Tehuacán (16 municipios), Teziutlán (31 municipios) y Zacatlán (12 municipios). Los poblados tomados como referencia para determinar los costos de transporte entre las diferentes regiones fueron los municipios de Acajete, Chila Honey, Chietla, Chalchicomula de Sesma, Palmar de Bravo, Tehuacán, Tlatlauquitepec y Chignahuapan. La integración de cada región y su ubicación geográfica se presenta en la Figura 1. Se consideraron dos orígenes imports. In the three scenarios the regional offer can increase from the situation observed to the potential situation to displace imports. Scenario 1 considered a reduction of $25 \%$ in state imports, and Scenarios 2 and 3 a reduction of 50 and $75 \%$, respectively. The three scenarios took into account the potential production as maximum limit. The most competitive regions would be those where the production increases when imports are reduced in a lower percentage. Because the increase in production is not enough to cover the yellow maize deficit in the state, in the scenarios only the purchase of white maize is reduced. Assuming the inexistence of surface damaged, a new potential production was obtained, using the potential yield and the surface sown, and three new scenarios were performed, with a reduction of yellow maize state imports of $15 \%$ (Scenario 1), $30 \%$ (Scenario 2) and $50 \%$ (Scenario 3).

In the three scenarios the production of maize in irrigation and rainfed zones are considered as an

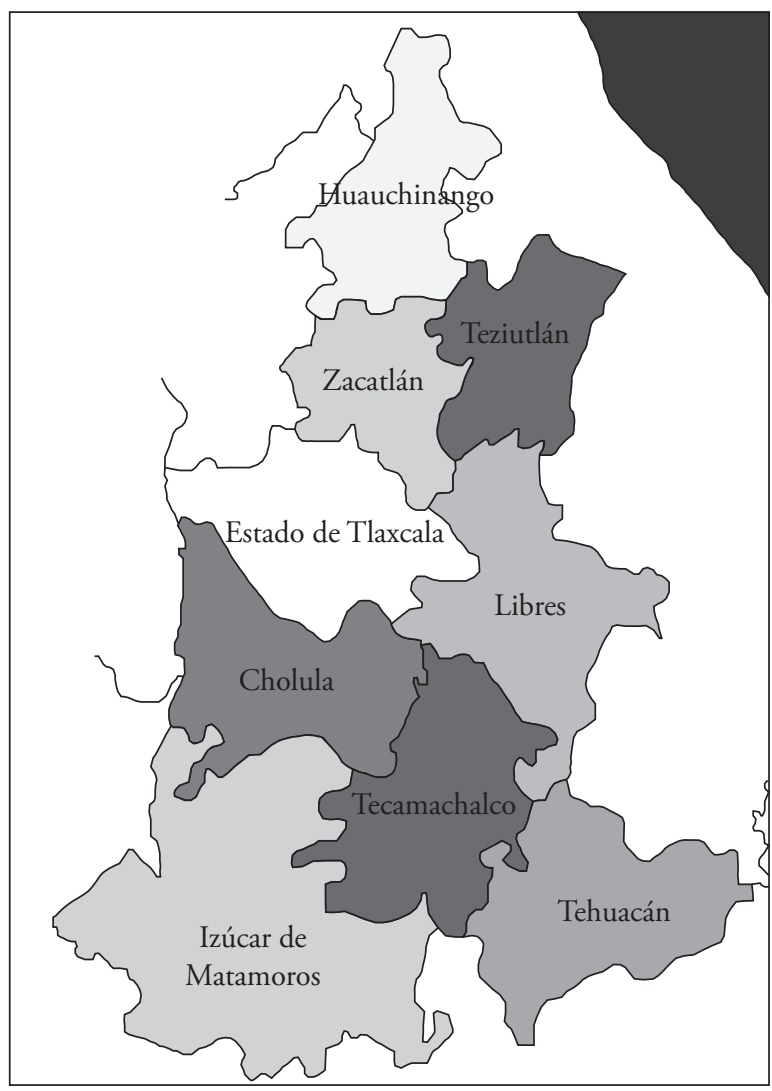

Figura 1. Ubicación geográfica de las regiones consideradas en el modelo.

Figure 1. Geographical location of the regions considered in the model. 
del maíz que recibe la entidad. El primero es el puerto de Veracruz, punto de internación de las importaciones de maíz amarillo proveniente del extranjero; el segundo corresponde a Sinaloa, principal proveedor de maíz blanco del estado.

\section{Datos}

Para obtener la solución del modelo se obtuvo una gran cantidad de información sobre las principales variables relacionadas con el mercado de maíz en el estado de Puebla.

La información sobre producción de maíz blanco y amarillo para cada región, régimen hídrico y ciclo de producción fue obtenida del Servicio de Información Agroalimentaria y Pesquera de la Secretaría de Agricultura, Ganadería, Desarrollo Rural, Pesca y Alimentación (SIAP-SAGARPA, 2012a). Se tomó en cuenta un promedio de tres ciclos de producción, iniciando en octubre de 2008 y finalizando en septiembre de 2010.

Debido a la inexistencia de información sobre consumos estales-regionales-municipales aparentes se realizó una estimación del consumo para cada región considerada en la entidad. El consumo estatal aparente fue desagregado según su uso y posteriormente se realizaron algunas ponderaciones para distribuirlo entre las regiones consideradas. Se consideraron los siguientes sectores consumidores de maíz blanco: industria de tortilla y molienda de nixtamal, sector pecuario y sector rural. Los ponderadores usados para obtener los datos regionales fueron: valor de la producción estatal de la industria de la tortilla y molienda de nixtamal, población de las principales especies animales y la población en el sector rural. La información usada para realizar la estimación provino del INEGI (2007), INEGI (2009), INEGI (2010) y García y Ramírez (2012). Para obtener el consumo de maíz blanco por semilla a nivel regional se multiplicó la superficie sembrada por la densidad de siembra. La superficie sembrada se obtuvo del SIAP-SAGARPA (2012a). La densidad promedio de siembra corresponde a la obtenida en las tecnologías de riego y temporal en el estado. El consumo por mermas se obtuvo multiplicando la producción anual por un porcentaje de $4.14 \%$ reportado por el SIAP en su reporte Balanza Disponibilidad-Consumo. La información utilizada provino del SIAP-SAGARPA (2012b). endogenous variable. When decreasing imports, the maize offer increases in a range that goes from the current to the potential production.

The model considered two varieties of maize: white and yellow. The spatial dimension was incorporated into the model, dividing the state into eight producing and consuming regions. The definition of regions was done taking into account the classification of Irrigation Districts reported by the Ministry of Agriculture, Livestock Production, Rural Development, Fishery and Food (Secretaría de Agricultura, Ganadería, Desarrollo Rural, Pesca y Alimentación, SIAP-SAGARPA, 2012a). The regions considered are: Cholula (made up of 34 municipalities), Huauchinango (20 municipalities), Izúcar de Matamoros (45 municipalities), Libres (24 municipalities), Tecamachalco (32 municipalities), Tehuacán (16 municipalities), Teziutlán (31 municipalities) and Zacatlán (12 municipalities). The towns taken as reference to determine the transportation costs between the different regions were the municipalities of Acajete, Chila Honey, Chietla, Chalchicomula de Sesma, Palmar de Bravo, Tehuacán, Tlatlauquitepec and Chignahuapan. The integration of each region and its geographical location are presented in Figure 1. Two origins of the maize that the state receives were considered. The first is the port of Veracruz, point of entry for yellow maize imports from abroad; the second is Sinaloa, primary supplier of white maize for the state.

\section{Data}

In order to obtain the model's solution, a large amount of information was obtained regarding the principal variables related to the maize market in the state of Puebla.

The information on white and yellow maize production for each region, water regime and cycle of production was obtained from the Agro-food and Fishery Information service of the Ministry of Agriculture, Livestock Production, Rural Development, Fishery and Food (SIAP-SAGARPA, 2012a). An average of three production cycles was taken into account, beginning on October 2008 and ending in September 2010.

Due to the lack of information about apparent state-regional-municipal consumption, an estimation of consumption for each region considered in the state was performed. The apparent state 
El maíz amarillo se consume principalmente en la industria de alimentos balanceados de manera representativa. Para estimar la cantidad consumida por región se usó como ponderador el valor de la producción nacional de la industria de alimentos balanceados dada por INEGI (2009). Para el cálculo del consumo de maíz amarillo para semilla y por mermas, la metodología usada fue similar al cálculo del consumo de maíz blanco. La información necesaria para la estimación del consumo de maíz amarillo provino del INEGI (2009) y de García y Ramírez (2012).

Considerando algunas estadísticas del Sistema Nacional de Información e Integración de Mercados (SNIIM, 2012) se consideraron dos principales entradas de maíz al estado: uno corresponde al blanco, proveniente de Sinaloa, y el otro al amarillo, el cual se importa de los EE. UU., internándose por Veracruz. Las cantidades provenientes de fuera del estado se calcularon restando al consumo la producción de maíz blanco y amarillo.

Los costos de producción se obtuvieron directamente en la Secretaría de Desarrollo Rural en el Estado de Puebla. ${ }^{1}$ Los costos de transporte se calcularon utilizando matrices de distancias (camión y ferrocarril) que conectan las zonas productoras y puntos de internación con las consumidoras. La información sobre tarifas de transporte se obtuvieron de la Secretaría de Comunicaciones y Transportes (SCT, 2012).

Los precios al consumidor se obtuvieron sumando los costos promedio de trasporte de llevar maíz de las zonas productoras a las consumidoras más el precio medio rural en las regiones productoras de Puebla. La información provino de SIAP-SAGARPA (2012a).

La estimación de la producción potencial se basó en el municipio líder, aquel que presenta el mayor rendimiento en una misma región (en este caso en un mismo DDR). Se parte del supuesto de que si los productores de todos los municipios que integran la región utilizan la misma tecnología, entonces el rendimiento de maíz en éstos podría aumentar hasta el nivel observado por el municipio líder. Para calcular el potencial productivo se usó la superficie total promedio del periodo 2008/2010 y el rendimiento potencial, el cual se obtuvo tomando el mayor rendimiento municipal registrado en los municipios que integran cada región considerada en el modelo. Los datos sobre superficie y rendimiento se obtuvieron del SIAP-SAGARPA (2012a). consumption was disaggregated based on its use and some weighing was performed later to distribute it between the regions considered. The following white maize consuming sectors were considered: tortilla and nixtamal grinding industry, livestock sector and rural sector. The weights used to obtain the regional data were: value of state production by the tortilla and nixtamal grinding industry, population of the principal animal species, and population in the rural sector. The information used to perform the estimation was originally from INEGI (2007), INEGI (2009), INEGI (2010) and García and Ramírez (2012). To obtain the consumption of white maize per seed at the regional level, the surface sown was multiplied by the density of sowing. The surface sown was obtained from SIAP-SAGARPA (2012a). The average density of sowing corresponds to that obtained with irrigation and rainfed technologies in the state. Consumption per losses was obtained by multiplying the annual production by a percentage of $4.14 \%$ reported by the SIAP in its AvailabilityConsumption Balance report. The information used was from SIAP-SAGARPA (2012b).

Yellow maize is consumed primarily in the balanced meal industry, in a representative manner. In order to estimate the amount consumed per region, the value of national production in the balanced meal industry provided by INEGI (2009) was used as weight. For the calculation of yellow maize consumption per seed and losses, the methodology used was similar to the calculation of white maize. The necessary information for the estimation of yellow maize consumption came from INEGI (2009) and García and Ramírez (2012).

Taking into account some statistics from the National System of Information and Integration of Markets (Sistema Nacional de Información e Integración de Mercados, SNIIM, 2012), two principal maize entries to the state are considered: one corresponds to white maize from Sinaloa, and the other to yellow maize, which is imported from the USA, entering through Veracruz. The amounts from out-of-state were calculated by subtracting the production of white and yellow maize from the consumption.

The production costs were obtained directly from the state of Puebla's Ministry of Rural Development. ${ }^{1}$ The transportation costs were calculated by using distance matrices (truck and train) that connect the producing zones and points of entry of consuming zones. The information about transportation fees were 
La solución del modelo fue estimada usando el MINOS escrito en el lenguaje de programación GAMS (General Algebraic Modeling Systems).

\section{Resultados y Discusión}

En el año promedio 2008-2010 la producción total de maíz en el estado de Puebla fue de 852 mil ton, de las cuales 847 mil fueron de maíz blanco (99\% de la producción estatal) y las restantes 5 mil ton corresponden a maíz amarillo (SIAP-SAGARPA, 2012a). Los distritos más importantes en la producción de maíz son Libres y Cholula, los cuales producen $60 \%$ de la producción total en el estado, con un total de $267 \mathrm{mil}$ y 244 mil ton, respectivamente. A pesar de su alta producción, Cholula no alcanza a abastecer internamente su consumo, presentando un déficit de 33 mil ton de maíz blanco, en contraste con la región de Libres que presenta un superávit de 126 mil ton (Cuadro 1).

A excepción del distrito de Libres, en Puebla, todas las regiones son deficitarias. El déficit total del estado es de 886 mil ton, de las cuales $44.5 \%$ corresponde a maíz blanco y $55.5 \%$ a amarillo. Las regiones consumidoras más de maíz amarillo más importantes son Tehuacán y Tecamachalco, con $97.9 \%$ del total consumido en el estado (482 mil ton). Estas dos regiones se abastecen casi en su totalidad de importaciones provenientes de los Estados Unidos que entran por Veracruz (Cuadro 1).

En el Cuadro 1 se presenta la producción y el saldo del comercio en una situación potencial. El consumo de maíz blanco es de 1,242 mil toneladas y la producción potencial es de 1226 mil toneladas, resultando un saldo de -16 mil toneladas. Las cifras anteriores indican que el potencial productivo que existe en la entidad casi cubre el déficit de maíz blanco; es decir, que el de amarillo seguirá siendo abastecido con importaciones provenientes del exterior.

En el Cuadro 2 se presenta la producción de maíz blanco por régimen hídrico observada en el periodo 2008-2010 de cada región y el aumento de ésta al disminuir las importaciones de dicho maíz bajo diferentes escenarios. Debido a que el potencial productivo de la entidad casi cubre su consumo, los escenarios que se presentan solo consideran su aumento; esto implica que no consideran la sustitución de maíz amarillo por blanco. En los tres escenarios se tomó en cuenta el potencial productivo calculado con la superficie cosechada y el rendimiento potencial. obtained from the Ministry of Communications and Transport (Secretaria de Comunicaciones y Transportes, SCT, 2012).

The prices for consumers were obtained by adding the average costs of transportation from shipping maize from the producing zones to the consuming zones, plus the mean rural price in the producing regions of Puebla. The information was from SIAPSAGARPA (2012a).

The estimation of potential production was based on the leading municipality, the one that presents the highest yield in the same region (in this case the same DDR). It stems from the assumption that if the producers from all the municipalities that make up the region use the same technology, then the maize yield in each of them could increase to the level observed at the leading municipality. To calculate the productive potential, the average total surface for the $2008 / 2010$ was used, and the potential yield, obtained by taking the highest municipal yield recorded in the municipalities that integrate each region considered in the model. The data about surface and yield were obtained from SIAP-SAGARPA (2012a).

The model solution was estimated by using the MINOS written in the GAMS programming language (General Algebraic Modeling Systems).

\section{Results AND Discussion}

In the average year 2008-2010, the total production of maize in the state of Puebla was 852 thousand tons, of which 847 thousand were white maize (99\% of the state production) and the other 5 thousand tons correspond to yellow maize (SIAPSAGARPA, 2012a). The most important districts in maize production are Libres and Cholula, which produce $60 \%$ of the state's total production, with a total of 267 thousand and 244 thousand tons, respectively. In spite of its high production, Cholula cannot supply its consumption internally, presenting a deficit of 33 thousand tons of white maize, in contrast with the region of Libres that presents a surplus of 126 thousand tons (Table 1).

Except for the district of Libres, Puebla, all the regions present deficit. The total state deficit is 886 thousand tons, of which $44.5 \%$ correspond to white maize and $55.5 \%$ to yellow maize. The most important consuming regions for yellow maize are 
Cuadro 1. Producción, consumo y saldo de comercio de maíz por región en Puebla.

Table 1. Production, consumption and commercial balance of maize per region in Puebla.

\begin{tabular}{|c|c|c|c|c|c|c|c|}
\hline \multirow{4}{*}{ Región } & \multicolumn{2}{|c|}{ Producción } & \multirow{2}{*}{ Consumo } & \multirow{2}{*}{ Saldo } & \multicolumn{2}{|c|}{ Producción } & \multirow{2}{*}{ Saldo } \\
\hline & Riego & Temporal & & & Riego & Temporal & \\
\hline & \multicolumn{4}{|c|}{$2008 / 2010$} & \multicolumn{3}{|c|}{ Potencial } \\
\hline & \multicolumn{7}{|c|}{ Miles de toneladas } \\
\hline \multicolumn{8}{|c|}{ Maíz blanco } \\
\hline Cholula & 26 & 218 & 277 & -33 & 39 & 292 & 54 \\
\hline Huauchinango & 2 & 29 & 108 & -76 & 2 & 45 & -60 \\
\hline Izucar de Matamoros & 23 & 51 & 208 & -134 & 25 & 118 & -65 \\
\hline Libres & 33 & 234 & 141 & 126 & 37 & 306 & 202 \\
\hline Tecamachalco & 82 & 39 & 190 & -69 & 116 & 81 & 6 \\
\hline Tehuacán & 10 & 15 & 113 & -88 & 12 & 21 & -80 \\
\hline Teziutlán & 0 & 60 & 138 & -79 & 0 & 98 & -41 \\
\hline Zacatlán & 7 & 18 & 67 & -42 & 9 & 26 & -31 \\
\hline Puebla & 183 & 665 & 1242 & -394 & 240 & 986 & -16 \\
\hline \multicolumn{8}{|c|}{ Maíz amarillo } \\
\hline Cholula & 0 & 0 & 14 & -14 & 0 & 0 & -14 \\
\hline Huauchinango & 0 & 2 & 0 & 1 & 0 & 2 & 1 \\
\hline Izúcar de Matamoros & 0 & 0 & 0 & 0 & 0 & 0 & 0 \\
\hline Libres & 0 & 0 & 0 & 0 & 0 & 0 & 0 \\
\hline Tecamachalco & 0 & 0 & 208 & -208 & 0 & 0 & -208 \\
\hline Tehuacán & 0 & 0 & 274 & -274 & 0 & 0 & -274 \\
\hline Teziutlán & 0 & 0 & 0 & 0 & 0 & 0 & 0 \\
\hline Zacatlán & 1 & 2 & 0 & 3 & 1 & 3 & 4 \\
\hline Puebla & 1 & 4 & 496 & -492 & 1 & 5 & -491 \\
\hline \multicolumn{8}{|c|}{ Maíz blanco más amarillo } \\
\hline Cholula & 26 & 218 & 291 & -47 & 39 & 292 & 40 \\
\hline Huauchinango & 2 & 31 & 108 & -74 & 2 & 47 & -59 \\
\hline Izúcar de Matamoros & 23 & 51 & 208 & -134 & 25 & 118 & -65 \\
\hline Libres & 33 & 234 & 141 & 126 & 37 & 306 & 202 \\
\hline Tecamachalco & 82 & 39 & 399 & -278 & 116 & 81 & -202 \\
\hline Tehuacán & 10 & 15 & 387 & -361 & 12 & 21 & -354 \\
\hline Teziutlán & 0 & 60 & 138 & -79 & 0 & 98 & -41 \\
\hline Zacatlán & 8 & 20 & 67 & -40 & 10 & 29 & -28 \\
\hline Puebla & 184 & 668 & 1738 & -886 & 241 & 991 & -506 \\
\hline
\end{tabular}

Fuente: elaborado con información obtenida de: SIAP-SAGARPA (2012a), INEGI (2007), INEGI (2009), INEGI (2010), García y Ramírez (2012) y SIAP-SAGARPA (2012b). u Source: elaborated with information from: SIAP-SAGARPA (2012a), INEGI (2007), INEGI (2009), INEGI (2010), García and Ramírez (2012), and SIAP-SAGARPA (2012b).

Bajo el Escenario 1 las importaciones de maíz blanco disminuyen $25 \%$ (de 394 a 295 mil ton). La región más competitiva sería Cholula, seguida de Tecamachalco y Libres con un aumento en la producción total (riego+temporal) de $57 \mathrm{mil}, 34 \mathrm{mil} \mathrm{y} 4 \mathrm{mil}$
Tehuacán and Tecamachalco, with $97.9 \%$ of the total consumed in the state (482 thousand tons). These two regions are supplied almost entirely with imports from the United States that enter through Veracruz (Table 1). 
Cuadro 2. Determinación de regiones competitivas en la producción de maíz en el Estado de Puebla. Table 2. Determination of competitive regions in maize production of the state of Puebla.

\begin{tabular}{|c|c|c|c|c|c|c|c|c|}
\hline \multirow{3}{*}{ Región } & \multirow{2}{*}{$\begin{array}{l}\text { Producción } \\
\text { riego } \\
2008 / 2010\end{array}$} & \multicolumn{3}{|c|}{$\begin{array}{l}\text { Aumento en la producción cuando las } \\
\text { importaciones disminuyen en: }\end{array}$} & \multirow{2}{*}{$\begin{array}{c}\text { Producción } \\
\text { temporal } \\
2008 / 2010\end{array}$} & \multicolumn{3}{|c|}{$\begin{array}{l}\text { Aumento en la producción cuando } \\
\text { las importaciones disminuyen en: }\end{array}$} \\
\hline & & $25 \%$ & $50 \%$ & $75 \%$ & & $25 \%$ & $50 \%$ & $75 \%$ \\
\hline & \multicolumn{8}{|c|}{ Toneladas } \\
\hline Cholula & 25604 & 12813 & 285 & 0 & 218171 & 43599 & 36944 & 0 \\
\hline Huauchinango & 2390 & 0 & 0 & 2 & 29431 & 0 & 0 & 15795 \\
\hline Izúcar de Matamoros & 22903 & 1994 & 0 & 0 & 50966 & 0 & 295 & 0 \\
\hline Libres & 32747 & 3756 & 0 & 0 & 234211 & 0 & 67981 & 3783 \\
\hline Tecamachalco & 82087 & 33969 & 0 & 0 & 38879 & 0 & 0 & 0 \\
\hline Tehuacán & 10369 & 0 & 0 & 1810 & 14932 & 0 & 0 & 0 \\
\hline Teziutlán & 0 & 0 & 0 & 0 & 59727 & 0 & 0 & 37923 \\
\hline Zacatlán & 6808 & 2463 & 0 & 0 & 18209 & 0 & 0 & 138 \\
\hline Puebla & 182908 & 54995 & 285 & 1812 & 664526 & 43599 & 105220 & 57639 \\
\hline
\end{tabular}

Fuente: elaboración propia con datos obtenidos de la solución del modelo. • Source: authors' elaboration with data obtained from the model solution.

ton, respectivamente. El aumento en la producción se lograría a través de un mayor rendimiento por ha, el cual se podría alcanzar usando variedades de semillas mejoradas, sin tener que incrementar la superficie. En este escenario la modalidad de riego es más competitiva encon relación con el temporal, con un porcentaje de $55.5 \%$ en el aumento total en la producción. Las regiones menos competitivas serían Tehuacán, Teziutlán y Huauchinango, con un nulo aumento en su producción.

Al disminuir las importaciones de maíz blanco en un $50 \%$, lo que significa bajar las importaciones en 197 mil ton, la zona más competitiva sería Libres, al aumentar su producción total en $68 \mathrm{mil}$ ton; cabe resaltar que todo el aumento corresponde a la modalidad de temporal. La segunda región más competitiva sería Cholula, con un amento total de 37 mil ton; Izúcar de Matamoros sería una nueva región que aumentaría su producción en 295 ton. En el resto de las regiones la producción no aumenta debido a la lejanía de los centros de consumo, lo que se traduce en mayores costos de distribución.

En el Escenario 3 las importaciones de maíz blanco disminuyen en $75 \%$, ubicándose en 138 mil ton. Por la disminución de las importaciones la producción de Teziutlán aumentaría en $38 \mathrm{mil}$ ton, seguido por Huauchinango y Libres con un aumento en la oferta de 16 y 4 mil ton.
Table 1 shows the production of the state and the commerce balance in a potential situation. The consumption of white maize is 1242 thousand tons and the potential production is 1226 thousand tons, resulting in a balance of -16 thousand tons. These figures indicate that the productive potential in the state almost covers the white maize deficit; that is, the one for yellow maize will continue to be supplied with imports from abroad.

In Table 2 the production of white maize per water regime observed in the 2008-2010 period is presented for each region, and its increase when decreasing the imports of this maize under different scenarios. Because the productive potential of the entity almost covers its consumption, the scenarios presented only consider its increase; this implies that they do not consider the substitution of yellow maize for white. In the three scenarios, the productive potential calculated with the surface harvested and the potential yield, were taken into account.

Under Scenario 1, white maize imports decrease $25 \%$ (from 394 to 295 thousand tons). The most competitive region would be Cholula, followed by Tecamachalco and Libres with an increase in total production (irrigation+rainfed) of 57 thousand, 34 thousand and 4 thousand tons, respectively. The increase in production would be achieved through a higher yield per ha, which could be attained by using improved seed varieties, without having to increase 
Los resultados del modelo indican que la producción de maíz bajo condiciones de riego es más competitiva econ relación con las de temporal. Al disminuir las importaciones de manera gradual, primero aumenta la producción bajo riego, esto debido a la posibilidad de obtener mayores rendimientos; la superficie siniestrada es menor y, por lo tanto, el costo medio de producción es menor comparado con las zonas de temporal.

Suponiendo la inexistencia de superficie siniestrada, se alcanzaría una producción potencial de 1.53 millones de ton; dicha cantidad permite abastecer la demanda de maíz blanco (1.24 millones de ton) y se tendría un exceso de producción. Es importante mencionar que una reducción en la superficie siniestrada podría venir de: a) un aumento en el uso de semillas mejoradas resistentes a la sequía; y b) el uso de fertilizantes adecuados y un buen control de plagas y enfermedades. En el Cuadro 3 se presenta la producción de maíz blanco observada, así como los diferentes escenarios que consideran una reducción gradual en las importaciones.

$\mathrm{Al}$ reducir las importaciones de maíz amarillo en 15 \% (de 492 mil a 418 mil ton), la región más competitiva sería Libres pues la producción (de riego más temporal) aumentaría en 164 mil ton, pasando de 267 mil a 431 mil ton. La segunda región más competitiva sería Cholula, con un incremento en la pro- the surface. In this scenario the irrigation modality is more competitive than the rainfed conditions, with a percentage of $55.5 \%$ in the total increase of production. The least competitive regions would be Tehuacán, Teziutlán and Huauchinango, with null increase in their production.

When white maize imports are reduced in $50 \%$, which means decreasing the imports in 197 thousand tons, the most competitive zone would be Libres, increasing its total production in 68 thousand tons; it should be mentioned that the whole increase corresponds to rainfed conditions. The second most competitive region would be Cholula, with a total increase of 37 thousand tons; Izúcar de Matamoros would be a new region to increase its production in 295 tons. In the rest of the regions production does not increase because of the distance from consumption centers, which translates into higher distribution costs.

Under Scenario 3 the white maize imports decrease in $75 \%$, equivalent to 138 thousand tons. From the decrease in imports production in Teziutlán would increase in 38 thousand tons, followed by Huauchinango and Libres with an increase in offer of 16 and 4 thousand tons.

Results from the model indicate that maize production under irrigation is more competitive than under rainfed conditions. When decreasing the imports gradually, the production under irrigation

Cuadro 3. Determinación de regiones competitivas en la producción de maíz en Puebla, considerando la inexistencia de superficie siniestrada.

Table 3. Determination of competitive regions in maize production in Puebla, considering the inexistence of damaged surface.

\begin{tabular}{|c|c|c|c|c|c|c|c|c|}
\hline \multirow{3}{*}{ Región } & \multirow{2}{*}{$\begin{array}{l}\text { Producción } \\
\text { riego } \\
2008 / 2010\end{array}$} & \multicolumn{3}{|c|}{$\begin{array}{c}\text { Aumento en la producción cuando las } \\
\text { importaciones disminuyen en: }\end{array}$} & \multirow{2}{*}{$\begin{array}{c}\text { Producción } \\
\text { temporal } \\
2008 / 2010\end{array}$} & \multicolumn{3}{|c|}{$\begin{array}{l}\text { Aumento en la producción cuando } \\
\text { las importaciones disminuyen en: }\end{array}$} \\
\hline & & $25 \%$ & $50 \%$ & $75 \%$ & & $25 \%$ & $50 \%$ & $75 \%$ \\
\hline & \multicolumn{8}{|c|}{ Toneladas } \\
\hline Cholula & 25604 & 13098 & 0 & 0 & 218171 & 139336 & 0 & \\
\hline Huauchinango & 2390 & 2 & 0 & 0 & 29431 & 15795 & 0 & 0 \\
\hline Izúcar de Matamoros & 22903 & 1994 & 0 & 0 & 50966 & 16350 & 73776 & 0 \\
\hline Libres & 32747 & 3756 & 0 & 0 & 234211 & 159860 & 0 & 0 \\
\hline Tecamachalco & 82087 & 49326 & 399 & 0 & 38879 & 0 & 0 & 66695 \\
\hline Tehuacán & 10369 & 0 & 2532 & 0 & 14932 & 0 & 0 & 0 \\
\hline Teziutlán & 0 & 0 & 0 & 0 & 59727 & 0 & 63616 & 0 \\
\hline Zacatlán & 6808 & 2463 & 0 & 0 & 18209 & 0 & 20869 & 0 \\
\hline Puebla & 182908 & 70639 & 2931 & 0 & 664526 & 331341 & 158261 & 66695 \\
\hline
\end{tabular}

Fuente: elaboración propia con datos obtenidos de la solución del modelo. $\bullet$ Source: authors’ elaboration with data obtained from the model solution. 
ducción de 152 mil ton (de 244 mil a 396 mil ton). El tercer distrito más competitivo bajo este escenario es Tecamachalco, con un aumento en la producción total de 49 mil ton (de 121 mil a 170 mil ton).

Bajo el Escenario 2 las importaciones de maíz se reducirían en $30 \%$ (de 492 mil a 344 mil ton). La región más competitiva es Izúcar de Matamoros, con un aumento en la producción total de 74 mil ton; la segunda es Teziutlán, con 64 mil ton; y la tercera es Zacatlán, con un aumento en la producción de 21 mil ton.

En el Escenario 3, donde se reduce la importación de maíz en 50 \% (pasar de 492 mil a 246 mil ton) la región más competitiva y la única que se activa en el modelo es Tecamachalco, con un aumento en su producción de $67 \mathrm{mil}$ ton; las demás regiones no presentan incremento de producción. Las regiones más competitivas son aquellas que al reducir las importaciones en pequeña cantidad aumentan primero su producción para cubrir la sustitución de importaciones.

\section{Conclusiones}

Soluciones diversas de un modelo de equilibrio espacial e inter-temporal que analiza la distribución de la producción y el abasto del consumo de maíz en el estado de Puebla permiten concluir que ante una situación de escasez de maíz originado por una reducción en las importaciones, las zonas productoras de maíz más competitivas serían las de mayor rendimiento y las más cercanas a los centros de consumo. En un primer nivel de escasez del producto, la región más competitiva sería la zona productora de maíz bajo temporal de Cholula y las productoras de maíz bajo riego de Cholula y Tecamachalco. En un segundo nivel de escasez, la más competitiva sería la zona productora de maíz de temporal del distrito de Libres. Las regiones menos competitivas son Huauchinango y Teziutlán, las cuales tienen los menores rendimientos y se encuentran alejadas de los principales centros de consumo.

\section{Notas}

${ }^{1}$ Información proporcionada por el Ing. Miguel Huerta Pérez, Coordinador Estatal de SistemasProducto Puebla. Secretaría de Desarrollo Rural. Information provided by Engineer Miguel Huerta increases first, due to the possibility of obtaining greater yields; the surface damaged is less and, therefore, the average cost of production is lower compared to rainfed zones.

Assuming the inexistence of damaged surface, a potential production of 1.53 million tons would be reached; this amount allows supplying the white maize demand (1.24 million tons) and there would be an excess of production. It is important to mention that a reduction in damaged surface could result from: a) an increase in the use of improved seeds resistant to drought; and b) the use of adequate fertilizers and good plague and disease control. In Table 3, the production of white maize observed is shown, as well as the different scenarios that consider a gradual reduction of imports.

When reducing yellow maize imports in $15 \%$ (from 492 thousand to 418 thousand tons), the most competitive region would be Libres, since production (of irrigation plus rainfed conditions) would increase in 164 thousand tons, from 267 thousand to 431 thousand tons. The second most competitive region would be Cholula, with an increase in production of 152 thousand tons (from 244 thousand to 396 thousand tons). The third most competitive district under this scenario is Tecamachalco, with an increase in total production of 49 thousand tons (from 121 thousand to 170 thousand tons).

Under Scenario 2 maize imports would be reduced in $30 \%$ (from 492 thousand to 344 thousand tons). The most competitive region is Izúcar de Matamoros, with an increase in total production of 74 thousand tons; the second is Teziutlán, with 64 thousand tons; and the third is Zacatlán, with an increase in production of 21 thousand tons.

Under Scenario 3, where maize imports are reduced in $50 \%$ (from 492 thousand to 246 thousand tons), the most competitive region and the only one that is activated in the model is Tecamachalco, with an increase in production of 67 thousand tons; the other regions do not present an increase in production. The most competitive regions are those that, when imports are reduced in a small amount, increase their production first to cover the substitution of imports.

\section{Conclusions}

Various solutions of a spatial and inter-temporal equilibrium model that analyzes the distribution 
Pérez, State Coordinator for Puebla's Product-Systems. Rural Development Ministry.

\section{Literatura Citada}

Felstehausen, Herman and Heliodoro Díaz Cisneros. 1985. The strategy of rural development: the Puebla initiative. Human Organization 44(4): 285-292.

FAO (Food and Agriculture Organization). 2011 y 2012. The state of the world's land and water resources for food and agriculture (SOLAW)- Managing systems at risk. Rome, Italy.

García Salazar, José Alberto, y Rocío Ramírez Jaspeado. 2012. Demanda de Semilla Mejorada de Maíz en México: Identificación de Usos y Zonas de Producción con Mayor Potencial de Crecimiento. Centro Internacional de Mejoramiento de Maíz y Trigo (CIMMYT). Texcoco, Estado de México. 156 p.

García Salazar, José Alberto, Gabriela Rodríguez Licea, Abelardo Sáenz Torres y Samuel Rebollar Rebollar. 2006. Políticas para mejorar la competitividad de la producción de maíz y frijol en México. Revista Fitotecnia Mexicana 29 (Núm. Especial 2):115-121.

González Estrada, Adrián, y Mario Alferes Varela. 2010. Competitividad y ventajas comparativas de la producción de maíz en México. Revista Mexicana de Ciencias Agrícolas 1(3):381-396.

INEGI (Instituto Nacional de Estadística, Geografía e Informática). 2007. Censo agrícola, ganadero y forestal 2007. Disponible en http: //www.inegi.gob.mx (fecha de consulta. 20 de abril, 2012).

INEGI (Instituto Nacional de Estadística, Geografía e Informática). 2009. Censo económico 2009. Disponible en http://www. inegi.gob.mx (fecha de consulta. 4 de mayo, 2012).

INEGI (Instituto Nacional de Estadística, Geografía e Informática). 2010. Censo de población y vivienda. Disponible en http:// www.inegi.gob.mx (fecha de consulta. 8 de marzo, 2012).

Maddala, Gangadharrao Soundalyarao, and Ellen Miller. 1991. Microeconomía. Primera Edición en Español. Mc Graw Hill. $285 \mathrm{p}$.

Matus Gardea, Jaime Arturo, y Arturo Puente González (coord). 1992. Análisis Estatal de los Efectos de la Política Económica y Bases de la Estrategia para la Conversión de la Agricultura. Colegio de Postgraduados y Secretaría de Agricultura y Recursos Hidráulicos. Montecillo, Estado de México.

SAGARPA-CIMMYT (Secretaría de Agricultura, Ganadería, Desarrollo Rural, Pesca y

Alimentación-Centro Internacional de Mejoramiento de Maíz y Trigo). 2011. ¿Qué es MasAgro? Modernización Sustentable de la Agricultura Tradicional. Disponible en http://masagro.cimmyt. org/index.php/ique--es--masagro. (Consultado: 23 de septiembre de 2012)

SCT (Secretaría de Comunicaciones y Transportes). (2012. Rutas punto a punto. http://aplicaciones4.sct.gob.mx/sibuac_internet/ControllerUI?action=cmdEscogeRuta. (Consultado $25 \mathrm{de}$ agosto de 2012).

SAGARPA (Secretaría de Agricultura, Ganadería, Desarrollo Rural, Pesca y Alimentación). 2003. Competitividad de las Cadenas Agroalimentarias. Subsecretaría de Agricultura. Dirección General de Fomento a la Agricultura. Dirección de Competitividad. México, D.F. 24 p.

Salcedo Baca, Salomón, José Alberto García Salazar, y Miriam Sagarnaga Villegas. 1993. Política agrícola y maíz en México: hacia el of production and the supply of consumption for maize in the state of Puebla allow concluding that faced with situation of maize scarcity originated by a reduction in imports, the most competitive maize producing zones would be those of highest yield and nearest to the consumption centers. At a first level of product scarcity, the most competitive region would be the rainfed maize producing zone of Cholula and the irrigation maize producing zones of Cholula and Tecamachalco. At a second level of scarcity, the most competitive would be the rainfed maize producing zone of the district of Libres. The least competitive regions are Huauchinango and Teziutlán, which have the lowest yields and are far from the main consumption centers.

- End of the English version -

libre comercio norteamericano. Comercio Exterior 43(4):302310.

Sánchez Olarte, Josset, Felipe Álvarez Gaxiola, Miguel Sánchez Hernández, Fernando Manzo Ramos, y Luis Daniel Ortega Martínez. 2011. La pertinencia de la estrategia de operación del Plan Puebla en el contexto de la extensión parcialmente privatizada. Ra Ximhai 7(2): 281-295.

SIAP-SAGARPA (Servicio de Información Agroalimentaria y Pesquera-Secretaría de

Agricultura, Ganadería, Desarrollo Rural, Pesca y Alimentación). 2012a. Información básica, agricultura, producción anual. Disponible en www.siap.sagarpa.gob.mx (consultado: 2 de marzo de 2012).

SIAP-SAGARPA (Servicio de Información Agroalimentaria y Pesquera) Secretaría de Agricultura, Ganadería, Desarrollo Rural, Pesca y Alimentación). 2012b. Información Básica, Agricultura, Balanza Nacional Disponibilidad-Consumo. Disponible en: www.siap.sagarpa.gob.mx/index.php?option=com_content\&vi ew=article\&id=12\&Itemid=17. (Fecha de consulta: 2 de marzo de 2012).

SNIIM (Sistema Nacional de Información e Integración de Mercados). 2012. Precios al mayoreo de maíz. www.http://www. economia-sniim.gob.mx/nuevo/. (Consultado: 2 de junio de 2012).

Takayama, Takashi, and George G. Judge. 1971. Spatial and temporal price and allocation models. North -Holland Publishing Co., Amsterdam Holland. 528 p.

Turrent Fernández, Antonio. 2009. Potencial productivo de maíz en México. La Jornada del Campo. 13 de enero de 2009, Número 16. Disponible en: http://www.jornada. unam.mx/2009/01/13/ iluminaciones.html. (Fecha de consulta 20 de octubre de 2011).

Turrent Fernández, Antonio, Timothy A. Wise and Elise Garvey. 2012. Factibilidad de alcanzar el potencial productivo de maíz de México. Woodrow Wilson International Center for Scholars, GDAE Working Paper No. 12-03. 